\title{
琵琶湖産のコイ科以外の数種魚類の一般成分組成 および脂質の脂肪酸組成
}

\author{
小島朝子, 佐 藤 守, 吉中禮二, 池田静! 徳
}

(1986 年 5 月 6 日受理)

\author{
Chemical Components and Fatty Acid Composition of Lipids in Several \\ Fresh Water Fishes except Cyprinidae in Lake Biwa
Tomoko Kojima,*1 Mamoru Sato, ${ }^{* 2}$ Reiji Yoshinaka, ${ }^{* 2}$ and Shizunori Ikeda*3

\begin{abstract}
The proximate composition of various tissues and the fatty acid composition of their lipids in several fishes except Cyprinidae in Lake Biwa were determined in order to evaluate the nutritive value of fresh water fish. The fishes examined were namazu Silurus asotus, nijimasu Salmo gairdneri, biwamasu Oncorhynchus masou rhodurus, ayu Plecoglossus altivelis, ohkuchibasu Micropterus salmoides, bluegill Lepomis macrochirus, unagi Anguilla japonica, yoshinobori Rhinogobius brunneus, and isaza Chaenogobius isaza.

The results obtained were as follows.

(1) The contents of moisture, crude ash, crude protein and crude lipid in edible portions were $68.3-84.6,1.0-3.1,12.1-22.5$ and $1.2-16.2 \%$, respectively. The lipid contents in the edible portions of biwamasu and unagi were much higher than those in the edible portions of other fishes.

(2) Lipids of the edible portions were rich in palmitic acid $\left(\mathrm{C}_{1 \mathrm{a} ; 0}\right)$, palmitoleic acid $\left(\mathrm{C}_{1 \mathrm{~B}: 1 \omega \theta \theta}\right)$ and oleic acid $\left(\mathrm{C}_{18: 10 \theta}\right)$.

(3) The content of total polyunsaturated fatty acid was lower in lipids of the muscles or the whole bodies of fresh water fishes than in those of the muscles of marine fishes.
\end{abstract}

\section{㷋术魚類の栄養学的特改を明らかにすることを目的と して, 前報に括いて琵琶湖産コイ科魚類 7 種の一般成分 組成および脂質の脂肪酸組成について報告した。 本報 では琵琶湖産のコイ科以外の魚類 9 種について，一般成 分組成および脂質の脂肪酸組成を調べた結果を報告す る。}

\section{実験材料および方法}

試料魚 本実験に用いた試料魚の採取年月日，試料 数、体重，体長，分析部位拉よび歩留りを Table 1 に 示す。

陚料魚は 1984 年 5 月から 1985 年 3 月にかけて, 大 津市の淡水魚の仲買業者より，活魚または水揚げ直後の むのを睡入した。試料魚は氷詰にして実駼室に運び，入 手後 2 時間以内に分析洪した。さジマス，オオクチハ スヒヒワマス，小アユ、イサザについては季節的変動を
知るために，2３回特期をかえて採取し，分析した。

試料の調製 各魚体を Table 1 K示す分析部位に分 けた後，それぞれの試料をチョッハーにかけて細㚬し， 均質化して分析に用いた。ナマズ、ニジマス，ビワマ ス, 養殖アニ,オオクチバス,プルーギル, ウナギなど の比較的大きい魚については 1 尾を 1 検体とし, 小丁 二、ヨシノボリおよびイサザなどの比較的小さい魚につ

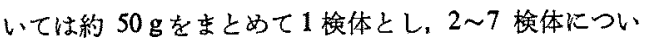
て分析した。

一般成分の分析 水分は常王加熱乾燥法, 粗灰分は乾 式灭化法，窒素はケルダール法，粗脂肪は Bligh と Dyer の方法 ${ }^{2}$ によって定量した。粗タンパク質含量は 垁素含量に 6.25 を乗じて求めた。

脂肪酸の分析 各組織から Bligh とDyer の方法2゙で 抽出した粗脂肪を，常法に従ってけん化，メチルエステ ル化した後, ガスクロマトグラフィーにより脂肪酸組成

*1 滋贺女子短期大学服飾学科 (Department of Home Economics, Shiga Women's Junior College, Tatsugaoka， Ohtsu 520, Japan).

*2 京都大学要学部水産学教室 (Department of Fisheries, Faculty of Agriculture, Kyoto University, Kyoto 606, Japan).

*3 近畿大学贯学部水学科 (Department of Fisheries, Faculty of Agriculture, Kinki University, Kowakae, Higashiosaka 577, Japan). 
Table 1. Samples used for analysis

\begin{tabular}{|c|c|c|c|c|c|c|c|}
\hline Species & & Date & Number & $\begin{array}{c}\text { Body weight } \\
(\mathrm{g})\end{array}$ & $\begin{array}{l}\text { Body length } \\
\text { (cm) }\end{array}$ & $\begin{array}{l}\text { Analyzed } \\
\text { parts }\end{array}$ & $\begin{array}{l}\text { Yield } \\
(\%)\end{array}$ \\
\hline $\begin{array}{l}\text { Namazu } \\
\text { Silurus asotus }\end{array}$ & & $\begin{array}{l}\text { May } 2 \\
1984\end{array}$ & 2 & $\begin{array}{c}556.0 \\
(413.0-699.0) \\
\end{array}$ & $\begin{array}{c}39.4 \\
(36.7-42.0)\end{array}$ & $\begin{array}{l}\text { Muscle } \\
\text { Liver } \\
\text { Ovary }\end{array}$ & $\begin{array}{r}40.6 \\
1.4 \\
7.9 \\
\end{array}$ \\
\hline \multirow[t]{3}{*}{$\begin{array}{l}\text { Nijimasu (Cultured) } \\
\text { Salmo gairdneri }\end{array}$} & (1) & $\begin{array}{l}\text { May } 16 \\
1984\end{array}$ & 6 & $\begin{array}{c}57.2 \\
(54.3-60.5) \\
\end{array}$ & $\begin{array}{c}16.4 \\
(15.8-17.0) \\
\end{array}$ & $\begin{array}{l}\text { Muscle } \\
\text { Liver } \\
\end{array}$ & $\begin{array}{c}46.7 \\
- \\
\end{array}$ \\
\hline & (2) & $\begin{array}{l}\text { Nov. } 13 \\
1984 \cdot\end{array}$ & 6 & $\begin{array}{c}57.8 \\
(47.4-65.0)\end{array}$ & $\begin{array}{c}15.1 \\
(14.4-15.6)\end{array}$ & $\begin{array}{l}\text { Muscle } \\
\text { Liver } \\
\text { Viscera }\end{array}$ & $\begin{array}{r}41.2 \\
1.3 \\
7.2 \\
\end{array}$ \\
\hline & (3) & $\begin{array}{l}\text { May } 15 \\
1984\end{array}$ & 3 & $\begin{array}{c}53.0 \\
(52.5-53.5) \\
\end{array}$ & $\begin{array}{c}16.0 \\
(15.7-16.2)\end{array}$ & Whole body & \\
\hline \multirow[t]{2}{*}{$\begin{array}{l}\text { Biwamasu } \\
\text { Oncorhynchus masou } \\
\text { rhodurus }\end{array}$} & (1) & $\begin{array}{l}\text { July } 14 \\
1984\end{array}$ & 3 & $\begin{array}{c}804.2 \\
(631.0-892.0)\end{array}$ & $\begin{array}{c}37.8 \\
(36.0-39.0)\end{array}$ & $\begin{array}{l}\text { Muscle } \\
\text { Liver } \\
\text { Ovary }\end{array}$ & $\begin{array}{r}57.3 \\
1.1 \\
2.4 \\
\end{array}$ \\
\hline & (2) & $\begin{array}{l}\text { Sep. } 10 \\
1984\end{array}$ & 2 & $\begin{array}{c}1411 \\
(1330-1492)\end{array}$ & $\begin{array}{c}45.2 \\
(43.8-46.6)\end{array}$ & $\begin{array}{l}\text { Muscle } \\
\text { Liver } \\
\text { Ovary } \\
\text { Testis } \\
\end{array}$ & $\begin{array}{r}46.8 \\
1.5 \\
11.9 \\
3.8 \\
\end{array}$ \\
\hline $\begin{array}{l}\text { Ayu (Cultured) } \\
\quad \text { Plecoglossus altivelis }\end{array}$ & & $\begin{array}{l}\text { May } 30 \\
1984\end{array}$ & 6 & $\begin{array}{c}62.3 \\
(56.4-69.7)\end{array}$ & $\begin{array}{c}15.9 \\
(15.2-16.6)\end{array}$ & $\begin{array}{l}\text { Muscle } \\
\text { Liver } \\
\text { Viscera }\end{array}$ & $\begin{array}{r}49.0 \\
1.1 \\
9.2 \\
\end{array}$ \\
\hline \multirow[t]{3}{*}{ Ayu (Wild) } & (1) & $\begin{array}{l}\text { June } 22 \\
1984 \\
\end{array}$ & $(500 \mathrm{~g})$ & - & - & Whole body & \\
\hline & (2) & $\begin{array}{l}\text { Mar. } 18 \\
1985 \\
\end{array}$ & $(500 \mathrm{~g})$ & $\begin{array}{r}4.2 \\
(\quad 2.8-\quad 5.8) \\
\end{array}$ & $\begin{array}{c}7.6 \\
(6.5-8.3) \\
\end{array}$ & Whole body & \\
\hline & (3) & $\begin{array}{l}\text { Mar. } 18 \\
1985\end{array}$ & $(100 \mathrm{~g})$ & $\begin{array}{c}1.0 \\
(0.8-1.3) \\
\end{array}$ & $\begin{array}{l}5.2 \\
(4.7-5.7) \\
\end{array}$ & Whole body & \\
\hline \multirow[t]{2}{*}{ Micropterus salmoides } & (1) & $\begin{array}{l}\text { June } 5 \\
1984\end{array}$ & 7 & $\begin{array}{c}159.6 \\
(113.8-216.1)\end{array}$ & $\begin{array}{c}19.0 \\
(17.9-21.1)\end{array}$ & $\begin{array}{l}\text { Muscle } \\
\text { Liver } \\
\text { Ovary } \\
\text { Testis } \\
\end{array}$ & $\begin{array}{r}40.7 \\
1.4 \\
4.0 \\
0.4 \\
\end{array}$ \\
\hline & (2) & $\begin{array}{l}\text { Oct. } 2 \\
1984\end{array}$ & 4 & $\begin{array}{c}649.8 \\
(562.1-860.7)\end{array}$ & $\begin{array}{c}28.7 \\
(26.2-31.6)\end{array}$ & $\begin{array}{l}\text { Muscle } \\
\text { Liver } \\
\text { Ovary } \\
\text { Testis } \\
\end{array}$ & $\begin{array}{r}39.8 \\
1.2 \\
0.7 \\
0.2 \\
\end{array}$ \\
\hline $\begin{array}{l}\text { Bluegill } \\
\quad \text { Lepomis macrochirus }\end{array}$ & & $\begin{array}{l}\text { Mar. } 1 \\
1985 \\
\end{array}$ & 3 & $\begin{array}{c}186.6 \\
(123.8-300.6) \\
\end{array}$ & $\begin{array}{c}15.8 \\
(14.3-18.3) \\
\end{array}$ & $\begin{array}{l}\text { Muscle } \\
\text { Liver }\end{array}$ & $\begin{array}{r}24.5 \\
1.3 \\
\end{array}$ \\
\hline $\begin{array}{l}\text { Unagi } \\
\text { Anguilla japonica }\end{array}$ & & $\begin{array}{l}\text { July } 18 \\
1984\end{array}$ & 3 & $\begin{array}{c}145.0 \\
(114.0-173.0)\end{array}$ & $\begin{array}{c}46.5 \\
(45.7-47.2)\end{array}$ & $\begin{array}{l}\text { Fillet } \\
\text { Liver } \\
\text { Viscera } \\
\end{array}$ & $\begin{array}{r}70.8 \\
1.4 \\
3.0 \\
\end{array}$ \\
\hline $\begin{array}{l}\text { Yoshinobori } \\
\text { Rhinogobius brunneus }\end{array}$ & & $\begin{array}{l}\text { Aug. } 28 \\
1984 \\
\end{array}$ & $(500 \mathrm{~g})$ & 0.034 & $\begin{array}{c}1.5 \\
(1.4-1.7) \\
\end{array}$ & Whole body & \\
\hline $\begin{array}{l}\text { Isaza } \\
\text { Chaenogobius isaza }\end{array}$ & (1) & $\begin{array}{l}\text { Oct. } 30 \\
1984 \\
\end{array}$ & $(500 \mathrm{~g})$ & $\begin{array}{c}2.9 \\
(2.6-3.3) \\
\end{array}$ & $\begin{array}{c}5.7 \\
(5.5-6.1) \\
\end{array}$ & Whole body & \\
\hline & $(2)$ & $\begin{array}{l}\text { Nov. } 21 \\
1984\end{array}$ & $(500 \mathrm{~g})$ & $\begin{array}{c}3.4 \\
(2.2-\quad 4.5) \\
\end{array}$ & $\begin{array}{c}6.0 \\
(5.1-6.7) \\
\end{array}$ & Whole body & \\
\hline
\end{tabular}

Values of body weight and length show the average and range (minimum-maximum) in parentheses. 
を求めだ。ガスクロマトグラフは島津 GC-8A 型，カラ ムは DEGS (10\%) を充塤したガラス $2 \mathrm{~mm} \times 2 \mathrm{~m}$ を 用いた。キャリアーガスとして $\mathrm{N}_{2}$ を $46 \mathrm{ml} / \mathrm{min} て ゙$ 流 し,カラムを $150^{\circ} \mathrm{C}$ から $200^{\circ} \mathrm{C}$ まで $3^{\circ} \mathrm{C} / \mathrm{min}$ の割合 で昇温した。試料注入温度は $220^{\circ} \mathrm{C}$ に設定した。脂肪酸 の同定は主な各種標準脂肪酸を用いて行った。

\section{詰果および考察}

各部位の步留りと一般成分粗成 琵琶湖産のコイ科以 外の魚類 9 種の各部位の歩留りと一般成分の分析結果を Table 1 と Table 2 に示す。

用いた 9 魚種の笳肉の歩留りは $24.5 \sim 57.3 \%$ の範用

Table 2. Chemical components of fresh water fishes in Lake Biwa

\begin{tabular}{|c|c|c|c|c|c|c|}
\hline \multirow{2}{*}{ Species } & \multirow{2}{*}{\multicolumn{2}{|c|}{$\begin{array}{l}\text { Analyzed } \\
\text { parts }\end{array}$}} & \multicolumn{4}{|c|}{ Component $(\%)$} \\
\hline & & & Moisture & Crude ash & Crude protein & Crude lipid \\
\hline \multirow[t]{3}{*}{ Namazu } & & Muscle & 78.7 & 1.2 & 19.1 & 3.8 \\
\hline & & Liver & 79.3 & 1.7 & 17.1 & 4.2 \\
\hline & & Ovary & 65.9 & 2.2 & 27.0 & 4.4 \\
\hline \multirow{6}{*}{$\begin{array}{l}\text { Nijimasu } \\
\quad \text { (Cultured) }\end{array}$} & (1) & Muscle & $78.5 \pm 1.4^{*}$ & $1.4 \pm 0.2$ & $20.2 \pm 0.7$ & $1.7 \pm 1.0$ \\
\hline & & Liver & 78.8 & 1.9 & 17.6 & 4.6 \\
\hline & (2) & Muscle & $76.4 \pm 0.8$ & $1.5 \pm 0.1$ & $21.2 \pm 0.5$ & $2.8 \pm 1.0$ \\
\hline & & Liver & $84.5 \pm 1.1$ & $1.3 \pm 0.7$ & $19.3 \pm 2.8$ & $5.8 \pm 1.6$ \\
\hline & & Viscera & - & - & - & 27.8 \\
\hline & (3) & Whole body & $77.9 \pm 1.2$ & $3.1 \pm 0.6$ & $19.1 \pm 0.7$ & $1.9 \pm 0.9$ \\
\hline \multirow[t]{7}{*}{ Biwamasu } & (1) & Muscle & $71.6 \pm 0.9$ & $1.1 \pm 0$ & $20.1 \pm 1.4$ & $12.2 \pm 0.9$ \\
\hline & & Liver & $72.8 \pm 1.2$ & $1.4 \pm 0.2$ & $17.2 \pm 0.5$ & $9.4 \pm 4.9$ \\
\hline & & Ovary & 60.2 & 1.4 & 24.0 & 15.0 \\
\hline & (2) & Muscle & 70.7 & 1.5 & 22.5 & 6.6 \\
\hline & & Liver & 79.0 & 1.4 & 15.7 & 7.5 \\
\hline & & Ovary & 54.7 & 1.6 & 28.3 & 14.6 \\
\hline & & Testis & 76.7 & 4.6 & 23.8 & 5.3 \\
\hline \multirow[t]{3}{*}{ Ayu (Cultured) } & & Muscle & $78.0 \pm 1.5$ & $1.0 \pm 0.1$ & $16.4 \pm 1.7$ & $5.5 \pm 1.3$ \\
\hline & & Liver & $83.6 \pm 1.0$ & 0.9 & 21.9 & $5.5 \pm 1.0$ \\
\hline & & Viscera & - & - & - & $56.1 \pm 6.0$ \\
\hline \multirow[t]{3}{*}{ Ayu (Wild) } & (1) & Whole body & $79.0 \pm 0.8$ & $2.1 \pm 0$ & $16.7 \pm 0.5$ & $3.2 \pm 0.5$ \\
\hline & (2) & Whole body & $79.7 \pm 0.4$ & $1.7 \pm 0$ & $15.7 \pm 0.4$ & $4.2 \pm 0.3$ \\
\hline & (3) & Whole body & 83.1 & 1.6 & 14.0 & 2.9 \\
\hline \multirow[t]{8}{*}{ Ohkuchibasu } & (1) & Muscle & $80.1 \pm 0.5$ & $1.3 \pm 0.1$ & $19.1 \pm 0.7$ & $1.2 \pm 0.4$ \\
\hline & & Liver & $79.7 \pm 0.8$ & $1.2 \pm 0.2$ & $15.4 \pm 1.2$ & $4.4 \pm 0.9$ \\
\hline & & Ovary & 65.0 & 1.4 & 20.7 & 11.9 \\
\hline & & Testis & 90.5 & 0.6 & 12.2 & 4.9 \\
\hline & (2) & Muscle & $78.3 \pm 1.8$ & $1.0 \pm 0.2$ & $18.7 \pm 2.5$ & $2.6 \pm 1.0$ \\
\hline & & Liver & $78.0 \pm 1.3$ & $0.6 \pm 0.2$ & $14.5 \pm 1.2$ & $5.6 \pm 0.6$ \\
\hline & & Ovary & $82.0 \pm 0.6$ & $1.4 \pm 0.5$ & $15.1 \pm 0.3$ & $4.0 \pm 0.7$ \\
\hline & & Testis & 83.3 & 1.0 & 11.1 & 3.4 \\
\hline \multirow[t]{2}{*}{ Bluegill } & & Muscle & $79.3 \pm 0.4$ & $1.0 \pm 0$ & $20.4 \pm 1.1$ & $1.5 \pm 1.2$ \\
\hline & & Liver & 72.4 & 0.7 & 13.8 & $3.4 \pm 0.3$ \\
\hline \multirow[t]{3}{*}{ Unagi } & & Fillet & $68.3 \pm 3.9$ & $1.2 \pm 0.2$ & $16.1 \pm 1.1$ & $16.2 \pm 1.4$ \\
\hline & & Liver & $75.5 \pm 4.5$ & $1.0 \pm 0.1$ & $14.1 \pm 3.4$ & $6.0 \pm 0.2$ \\
\hline & & Viscera & - & - & - & $5.9 \pm 3.6$ \\
\hline Yoshinobori & & Whole body & $84.6 \pm 0.3$ & $1.7 \pm 0.2$ & $12.1 \pm 0.2$ & $2.1 \pm 0.4$ \\
\hline \multirow[t]{2}{*}{ Isaza } & $(1)$ & Whole body & $77.6 \pm 0.7$ & $2.3 \pm 0.2$ & $16.4 \pm 1.7$ & $6.7 \pm 0.8$ \\
\hline & (2) & Whole body & $75.7 \pm 1.1$ & $2.5 \pm 0.2$ & $16.5 \pm 2.5$ & $4.9 \pm 0.3$ \\
\hline
\end{tabular}

\footnotetext{
- Mean \pm SD
} 
Table 3. Fatty acid composition of lipids of fresh water fishes in Lake Biwa

\begin{tabular}{|c|c|c|c|c|c|c|c|c|c|c|c|c|c|c|c|}
\hline \multirow{2}{*}{ Species } & & \multirow{2}{*}{$\begin{array}{c}\text { Analyzed } \\
\text { parts }\end{array}$} & \multicolumn{5}{|c|}{ Saturates } & \multicolumn{4}{|c|}{ Monoenes } & \multicolumn{4}{|c|}{ Dienes } \\
\hline & & & $14: 0$ & $16: 0$ & $17: 0$ & $18: 0$ & Total & $\begin{array}{r}16: 1 \\
\omega 9 \\
\end{array}$ & $\begin{array}{r}18: 1 \\
\omega 9 \\
\end{array}$ & $\begin{array}{r}20: 1 \\
\omega 9 \\
\end{array}$ & Total & $\begin{array}{r}18: 2 \\
\omega 6 \\
\end{array}$ & $\begin{array}{r}20: 2 \\
\omega 9\end{array}$ & $\begin{array}{r}20: 2 \\
\omega 6 \\
\end{array}$ & Total \\
\hline \multirow[t]{3}{*}{ Namazu } & & Muscle & 2.8 & 17.5 & 1.4 & 5.8 & $(27.5)$ & 12.6 & 21.0 & - & $(33.6)$ & 6.2 & 0.8 & 1.5 & $(8.5)$ \\
\hline & & Liver & 2.9 & 28.7 & 1.9 & 9.6 & $(43.1)$ & 13.9 & 22.4 & - & $(36.3)$ & 3.6 & 4.6 & - & $(8.2)$ \\
\hline & & Ovary & 2.5 & 21.6 & 1.6 & 7.3 & $(33.0)$ & 14.2 & 21.3 & - & $(35.5)$ & 4.3 & 0.3 & 1.0 & $(5.6)$ \\
\hline \multirow[t]{6}{*}{ Nijimasu } & (1) & Muscle & 1.6 & 18.8 & 0.4 & 5.5 & $(26.3)$ & 3.9 & 22.2 & 3.9 & $(30.0)$ & 13.3 & 0.5 & 1.5 & $(15.3)$ \\
\hline & & Liver & 1.0 & 20.4 & 0.6 & 5.8 & $(27.8)$ & 2.8 & 15.1 & 2.0 & $(19.9)$ & 8.6 & - & 1.2 & $(9.8)$ \\
\hline & (2) & Muscle & 2.2 & 20.2 & 0.3 & 4.1 & $(26.8)$ & 5.8 & 25.9 & 4.4 & $(36.1)$ & 12.1 & - & 1.2 & (13.3) \\
\hline & & Liver & 2.3 & 21.5 & 0.1 & 6.1 & $(30.0)$ & 5.4 & 27.3 & 2.7 & $(35.4)$ & 4.1 & - & 0.6 & $(4.7)$ \\
\hline & & Viscera & 2.8 & 21.7 & - & 5.1 & $(29.6)$ & 7.3 & 33.7 & 3.9 & $(44.9)$ & 13.6 & - & 0.5 & (14.1) \\
\hline & (3) & Whole body & 1.6 & 18.7 & 0.5 & 5.9 & $(26.7)$ & 4.1 & 22.8 & 4.5 & $(31.4)$ & 15.1 & 0.4 & 1.9 & $(17.4)$ \\
\hline \multirow[t]{7}{*}{ Biwamasu } & (1) & Muscle & 2.5 & 17.5 & 1.0 & 5.0 & $(26.0)$ & 9.3 & 28.8 & - & $(38.1)$ & 4.1 & 0.6 & 0.6 & $(5.3)$ \\
\hline & & Liver & 1.6 & 11.1 & 0.7 & 4.0 & $(17.4)$ & 10.0 & 31.9 & - & $(41.9)$ & 3.8 & 0.6 & 1.1 & $(5.5)$ \\
\hline & & Ovary & 2.1 & 12.3 & 0.6 & 3.1 & $(18.1)$ & 10.4 & 22.7 & - & $(33.1)$ & 4.0 & 0.7 & 0.7 & $(5.4)$ \\
\hline & (2) & Muscle & 2.8 & 15.8 & 0.8 & 3.4 & $(22.8)$ & 10.1 & 24.3 & - & $(34.4)$ & 4.7 & 1.2 & 0.4 & $(6.3)$ \\
\hline & & Liver & 3.0 & 17.0 & 0.7 & 4.6 & $(25.3)$ & 7.8 & 19.4 & - & $(27.2)$ & 2.9 & 0.9 & 0.2 & $(4.0)$ \\
\hline & & Ovary & 2.3 & 11.5 & 0.5 & 2.3 & $(16.6)$ & 11.1 & 20.6 & - & $(31.7)$ & 5.0 & 1.2 & 0.5 & $(6.7)$ \\
\hline & & Testis & 2.7 & 22.7 & 0.7 & 3.8 & $(29.9)$ & 5.3 & 16.8 & - & $(22.1)$ & 1.7 & 0.7 & 0.2 & $(2.6)$ \\
\hline \multirow{3}{*}{\multicolumn{2}{|c|}{ Ayu (Cultured) }} & Muscle & 4.2 & 28.9 & 0.3 & 2.7 & $(36.1)$ & 13.0 & 22.8 & 4.0 & $(39.8)$ & 10.2 & 0.4 & 0.1 & $(10.7)$ \\
\hline & & Liver & 3.4 & 27.6 & - & 2.8 & $(33.8)$ & 11.4 & 22.7 & 2.9 & $(37.0)$ & 8.0 & 0.7 & 0.9 & $(9.6)$ \\
\hline & & Viscera & 4.6 & 34.4 & 0.3 & 3.2 & $(42.5)$ & 12.1 & 21.2 & 3.9 & $(37.2)$ & 9.3 & 0.7 & 0.1 & (10.1) \\
\hline
\end{tabular}




\begin{tabular}{|c|c|c|c|c|c|c|c|c|c|c|c|c|c|c|c|}
\hline \multirow[t]{3}{*}{ Ayu (Wild) } & $(1)$ & Whole body & 5.9 & 19.9 & 1.3 & 5.6 & $(32.7)$ & 8.4 & 9.4 & - & $(17.8)$ & 5.6 & 2.9 & 0.3 & ( 8.8) \\
\hline & (2) & Whole body & 5.0 & 15.8 & 1.3 & 3.2 & $(25.3)$ & 12.9 & 13.0 & - & $(25.9)$ & 5.2 & 6.7 & 0.3 & $(12.2)$ \\
\hline & (3) & Whole body & 4.3 & 16.9 & 4.2 & 3.8 & $(29.2)$ & 11.6 & 12.4 & - & $(24.0)$ & 5.6 & 5.4 & - & $(11.0)$ \\
\hline \multirow[t]{8}{*}{ Ohkuchibasu } & (1) & Muscle & 2.1 & 20.1 & 1.0 & 5.1 & $(28.3)$ & 10.1 & 18.8 & - & $(28.9)$ & 5.7 & 0.4 & 1.0 & $(7.1)$ \\
\hline & & Liver & 1.3 & 19.5 & 0.8 & 6.7 & $(28.3)$ & 9.0 & 19.2 & - & $(28.2)$ & 2.5 & 0.2 & 0.5 & $(3.2)$ \\
\hline & & Ovary & 2.9 & 15.0 & - & 1.0 & (18.9) & 18.6 & 16.8 & - & $(35.4)$ & 6.5 & 0.7 & - & $(7.2)$ \\
\hline & & Testis & 2.6 & 16.8 & 1.1 & 4.7 & $(25.2)$ & 11.0 & 21.1 & - & (32.1) & 4.8 & 0.8 & 0.8 & $(6.4)$ \\
\hline & (2) & Muscle & 2.8 & 20.4 & 0.8 & 3.2 & $(27.2)$ & 13.3 & 24.2 & - & $(37.5)$ & 6.6 & 0.2 & 1.3 & $(8.1)$ \\
\hline & & Liver & 1.7 & 22.6 & 0.7 & 5.8 & $(30.8)$ & 12.3 & 20.1 & - & $(32.4)$ & 4.5 & 0.2 & 0.9 & $(5.6)$ \\
\hline & & Ovary & 2.3 & 21.3 & 1.1 & 3.6 & $(28.3)$ & 11.5 & 20.2 & - & $(31.7)$ & 5.6 & 0.4 & 1.1 & $(7.1)$ \\
\hline & & Testis & 2.1 & 23.3 & 1.1 & 8.2 & $(34.7)$ & 8.5 & 20.7 & - & $(29.2)$ & 4.4 & - & 0.6 & $(5.0)$ \\
\hline \multirow[t]{2}{*}{ Bluegill } & & Muscle & 2.3 & 25.1 & 0.8 & 4.2 & (32.4) & 9.0 & 21.4 & - & $(30.4)$ & 3.6 & - & 0.8 & $(4.4)$ \\
\hline & & Liver & 2.3 & 20.5 & 1.2 & 4.7 & $(28.7)$ & 15.1 & 21.7 & - & $(37.5)$ & 3.3 & - & 0.3 & $(3.6)$ \\
\hline \multirow[t]{3}{*}{ Unagi } & & Fillet & 3.9 & 19.3 & 0.8 & 4.4 & $(28.4)$ & 12.3 & 39.0 & - & $(51.3)$ & 4.2 & - & - & $(4.2)$ \\
\hline & & Liver & 1.9 & 19.5 & 0.7 & 6.8 & $(28.9)$ & 8.1 & 34.2 & - & (42.3) & 3.0 & 2.7 & - & $(5.7)$ \\
\hline & & Viscera & 3.5 & 17.4 & 0.9 & 5.4 & $(27.2)$ & 11.2 & 32.1 & - & (43.3) & 4.9 & 0.7 & - & $(5.6)$ \\
\hline Yoshinobori & & Whole body & 4.9 & 20.8 & 1.4 & 8.4 & $(35.5)$ & 4.3 & 12.0 & - & $(16.3)$ & 10.8 & 1.8 & 1.2 & (13.8) \\
\hline \multirow[t]{2}{*}{ Isaza } & (1) & Whole body & 3.7 & 14.3 & 1.2 & 5.1 & $(24.3)$ & 13.1 & 21.4 & - & $(34.5)$ & 5.1 & 2.4 & 1.0 & $(8.5)$ \\
\hline & (2) & Whole body & 3.5 & 14.9 & 0.9 & 4.9 & $(24.2)$ & 13.3 & 21.4 & - & $(34.7)$ & 4.8 & 2.1 & 0.9 & $(7.8)$ \\
\hline
\end{tabular}


Table 3. (Continued)

$(\%)$

\begin{tabular}{|c|c|c|c|c|c|c|c|c|c|c|c|c|c|}
\hline \multirow{2}{*}{ Species } & \multirow{2}{*}{\multicolumn{2}{|c|}{ Analyzed parts }} & \multicolumn{3}{|c|}{ Trienes } & \multicolumn{8}{|c|}{ Polyenes } \\
\hline & & & $\begin{array}{c}18: 3 \\
\omega 3\end{array}$ & $\begin{array}{l}20: 3 \\
\omega 6\end{array}$ & Total & $\begin{array}{c}20: 4 \\
\omega 6\end{array}$ & $\underset{\omega 3}{20: 4}$ & $\begin{array}{c}20: 5 \\
\omega 3\end{array}$ & $\begin{array}{c}22: 4 \\
\omega 6\end{array}$ & $\begin{array}{c}22: 5 \\
\omega 6\end{array}$ & $\begin{array}{c}22: 5 \\
\omega 3\end{array}$ & $\begin{array}{c}22: 6 \\
\omega 3\end{array}$ & Total \\
\hline \multirow[t]{3}{*}{ Namazu } & & Muscle & 5.8 & 0.9 & $(6.7)$ & 4.6 & 1.2 & 3.9 & 2.3 & 1.0 & 2.3 & 3.4 & $(18.7)$ \\
\hline & & Liver & 2.6 & 0.6 & $(3.2)$ & 5.0 & 0.5 & 3.8 & 2.2 & - & 1.7 & 3.0 & $(16.2)$ \\
\hline & & Ovary & 2.6 & 0.6 & $(3.2)$ & 5.1 & 0.6 & 4.3 & 1.8 & 0.3 & 2.2 & 4.6 & (18.9) \\
\hline \multirow[t]{6}{*}{ Nijimasu } & (1) & Muscle & - & 1.1 & (1.1) & 2.8 & 0.8 & 3.7 & 1.7 & 0.1 & 1.2 & 16.4 & $(26.7)$ \\
\hline & & Liver & - & 0.9 & $(0.9)$ & 3.3 & 0.5 & 3.9 & 0.9 & 0.3 & 1.2 & 32.3 & $(42.4)$ \\
\hline & (2) & Muscle & - & 0.7 & $(0.7)$ & 1.1 & 1.8 & 3.1 & 0.3 & 0.5 & 1.0 & 14.8 & $(22.6)$ \\
\hline & & Liver & . & 0.4 & $(0.4)$ & 2.2 & - & 3.1 & 0.2 & 0.3 & 0.6 & 23.2 & $(29.6)$ \\
\hline & & Viscera & - & - & $(-)$ & 0.6 & 1.7 & 2.0 & - & - & - & 7.0 & (11.3) \\
\hline & (3) & Whole body & - & 1.2 & $(1.2)$ & 3.8 & 1.4 & 3.8 & 2.1 & - & 1.1 & 10.2 & $(22.4)$ \\
\hline \multirow[t]{7}{*}{ Biwamasu } & (1) & Muscle & 3.5 & 0.4 & $(3.9)$ & 3.9 & 1.3 & 3.8 & 1.9 & 1.9 & 2.6 & 9.4 & $(24.8)$ \\
\hline & & Liver & 3.6 & 0.7 & (4.3) & 5.8 & 2.0 & 5.5 & 3.6 & 0.9 & 3.8 & 5.6 & $(27.2)$ \\
\hline & & Ovary & 4.2 & 0.6 & $(4.8)$ & 6.4 & 2.0 & 7.4 & 2.9 & 1.0 & 4.4 & 11.7 & $(35.8)$ \\
\hline & (2) & Muscle & 4.3 & 0.3 & $(4.6)$ & 3.5 & 1.8 & 3.9 & 1.4 & 2.6 & 3.4 & 13.4 & $(30.0)$ \\
\hline & & Liver & 3.7 & 0.2 & $(3.9)$ & 6.8 & 1.7 & 7.1 & 1.2 & 1.7 & 3.6 & 16.5 & $(38.6)$ \\
\hline & & Ovary & 4.9 & 0.6 & $(5.5)$ & 6.8 & 2.5 & 6.9 & 1.4 & $1: 2$ & 4.9 & 14.2 & (37.9) \\
\hline & & Testis & 2.0 & 0.2 & $(2.2)$ & 8.0 & 1.0 & 9.9 & 1.0 & 1.4 & 2.5 & 18.6 & $(42.4)$ \\
\hline \multirow[t]{3}{*}{ Ayu (Cultured) } & & Muscle & - & 0.2 & $(0.2)$ & 2.0 & 0.4 & 2.8 & 1.2 & - & 1.3 & 5.0 & $(12.7)$ \\
\hline & & Liver & - & 0.5 & $(0.5)$ & 2.5 & 0.5 & 2.4 & 2.5 & - & 1.7 & 8.7 & (18.3) \\
\hline & & Viscera & - & 0.2 & $(0.2)$ & 2.2 & 0.4 & 2.6 & 1.0 & - & 1.1 & 3.5 & $(10.8)$ \\
\hline
\end{tabular}

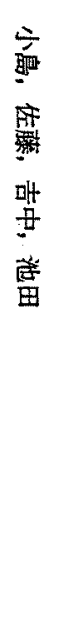




\begin{tabular}{|c|c|c|c|c|c|c|c|c|c|c|c|c|c|}
\hline \multirow[t]{3}{*}{ Ayu (Wild) } & (1) & Whole body & 5.7 & 0.3 & $(6.0)$ & 4.9 & 1.4 & 9.6 & 2.4 & 2.6 & 2.3 & 8.7 & (31.9) \\
\hline & (2) & Whole body & 5.8 & 2.0 & $(7.8)$ & 3.1 & 1.6 & 8.3 & 4.8 & 1.1 & 1.4 & 2.4 & $(22.7)$ \\
\hline & (3) & Whole body & 4.1 & 1.2 & $(5.3)$ & 3.8 & 1.2 & 9.4 & 6.5 & 1.9 & 0.4 & 6.0 & $(29.2)$ \\
\hline \multirow[t]{8}{*}{ Ohkuchibasu } & (1) & Muscle & 3.2 & 0.8 & $(4.0)$ & 7.1 & 0.9 & 4.5 & 2.3 & 1.8 & 2.9 & 8.8 & $(28.3)$ \\
\hline & & Liver & 1.8 & 0.4 & $(2.2)$ & 4.5 & 0.5 & 3.0 & 2.0 & 1.5 & 2.3 & 12.4 & (26.2) \\
\hline & & Ovary & 3.2 & 0.4 & $(3.6)$ & 4.8 & 2.3 & 6.7 & 2.2 & 0.9 & 2.3 & 8.6 & $(27.8)$ \\
\hline & & Test is & 3.7 & 0.6 & $(4.3)$ & 5.5 & 1.2 & 4.6 & 1.9 & 2.0 & 3.3 & 9.7 & (28.2) \\
\hline & (2) & Muscle & 5.1 & 0.6 & $(5.7)$ & 5.1 & 1.0 & 2.6 & 1.7 & 1.2 & 2.2 & 4.0 & $(17.8)$ \\
\hline & & Liver & 3.2 & 0.5 & $(3.7)$ & 4.8 & 1.0 & 1.9 & 2.7 & 1.5 & 3.2 & 8.4 & $(23.5)$ \\
\hline & & Ovary & 4.8 & 0.6 & $(5.4)$ & 6.3 & 1.1 & 2.7 & 1.8 & 1.9 & 2.2 & 7.0 & $(23.0)$ \\
\hline & & Testis & 2.7 & - & $(2.7)$ & 7.4 & - & 3.4 & 1.6 & 3.2 & 1.9 & 9.1 & $(26.6)$ \\
\hline \multirow[t]{2}{*}{ Bluegill } & & Muscle & 2.1 & 0.4 & $(.2 .5)$ & 9.2 & - & 5.3 & 3.1 & 1.5 & 2.7 & 6.5 & $(28.3)$ \\
\hline & & Liver & 1.6 & - & $(1.6)$ & 6.0 & 1.1 & 3.7 & 4.8 & 1.0 & 1.5 & 8.4 & (26.5) \\
\hline \multirow[t]{3}{*}{ Unagi } & & Fillet & 3.5 & 0.6 & $(4.1)$ & 2.3 & 0.9 & 1.7 & 0.8 & - & 1.2 & 1.1 & $(8.0)$ \\
\hline & & Liver & 2.4 & 1.1 & $(3.5)$ & 5.0 & 1.2 & 3.6 & 1.9 & 0.3 & 1.9 & 3.5 & (17.4) \\
\hline & & Viscera & 3.7 & 0.9 & $(4.6)$ & 4.3 & 1.2 & 2.9 & 1.9 & 0.4 & 2.0 & 1.8 & $(14.5)$ \\
\hline Yoshinobori & & Whole body & 3.6 & 1.1 & $(4.7)$ & 7.8 & 1.5 & 5.1 & 2.0 & 2.8 & 1.3 & 5.3 & (25.8) \\
\hline \multirow[t]{2}{*}{ Isaza } & (1) & Whole body & 5.5 & 0.6 & $(6.1)$ & 6.3 & 0.6 & 9.2 & 2.0 & 0.5 & 2.0 & 2.2 & (22.8) \\
\hline & (2) & Whole body & 5.2 & 0.4 & $(5.6)$ & 6.9 & 0.3 & 9.5 & 1.7 & 0.7 & 2.1 & 3.2 & $(24.4)$ \\
\hline
\end{tabular}


で、ブルーギルの歩留りが最も低かっだ。ウナギのフィ レーの歩留りは 70.8\% で，可食部の割合が高かった。

筋肉の水分含量はビワマス，ウナギを除いて 76.4 $80.1 \%$ の範团であっだ。ビロマス，ウナギの水分含量 は 68.3 71.6\% の籁囲で低かったが，これは粗脂肪含 量が高かったことと関連している。小型魚の全魚体の水 分含量注汪とんどが 75.7 79.7\% の範团であったが， 小フニやヨシノボリではそれぞれ $83.1 \%$ 扩上び $84.6 \%$ であった。報告されている海産魚類の筋肉の水分含量は 約 64 78\% の範柬8-3)でこれと比較すると測定した淡 水産魚類の筋肉の水分含量恃やや高加た。

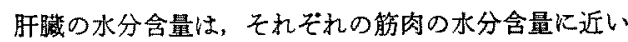
值を示した。10月採取のオオクキバスでは卵巣が未成熟 なためか，その水分含量は高かったが，その他の成熟卵 のそ机 54.7 65.9\% と低かった。

筋肉の粗灰分含量はいずれも $1.0 \sim 1.5 \%$ の範囲であ った。小型魚の全魚体の粗灰分含量は $1.6 \sim 3.1 \%$ で, 筋肉のそれ上りも高く、これらの小型魚はミネラルの良 い給源になると思われる。小アユとヨシノボリの粗灰分 含量は低からた。

筋肉の粗タンパク質含量仕 16.4 22.5\% の範囲で, コイ科魚類の筋肉タンパク質含量 が多かった。特に二ジマス扰よびビワマスの筋肉の粗タ ンパク質含量は $20 \%$ 上り多く，海産魚類のそれ゙-3) 敵した。ウナギのフィレーと竓殖アニの筋肉の粗タンパ ク質含量はそれぞれ $16.1 \%$ および $16.4 \%$ と低かった。 小型魚の全魚体の粗タンパク質含量は 15.7 19.1 の範 囲で，筋肉の粗タンハク質含量に比べてやや低かった。 小アニとヨシノボリではその含量はさらに低かった。ナ マズとビワマスの成熟卵の粗タンパク質含量は 24.0 $28.3 \%$ で著しく多かった。

粗脂肪含量は魚種による違いが大きかった。養殖了二 とビワマスの筋肉, ウナギのフィレーの粗脂肪含量は $5.5 \sim 16.1 \%$ の範国で著しく高い値を示した。一方， 7 月採取のオオクチバスの筋肉は $1.2 \%$ といら低い粗粗脂 肪含量で茜り，あっさりした淡白な味を呈するものと思 われる。小型魚で全魚体について測定したるののうちで は，イサザの粗脂肪含量が $6.7 \%$ と高かった。

䀒臓の粗脂肪含量は 3.4 9.4\% の範国で筋肉の之れ より高かった。成熟即の粗脂肪含量は $4.4 \sim 15.0 \%$ の範 囲で一般に高かった。

ビワマスの筋内の粗脂肪含量には時期によって大きな 变動がられた。

各部位の脂犋の脂肪酸組成 琵琶湖産の魚類 9 䊗の脂 質の脂肪酸成を調へた結果を Table 3 亿示す。

Table 3 から明らかなよらに，魚種，部位に関係なく $\mathrm{C}_{16: 0}, \mathrm{C}_{18: 1 \omega 9} お$ よび $\mathrm{C}_{18: 1 \omega 9}$ が多く、いずれる組成比

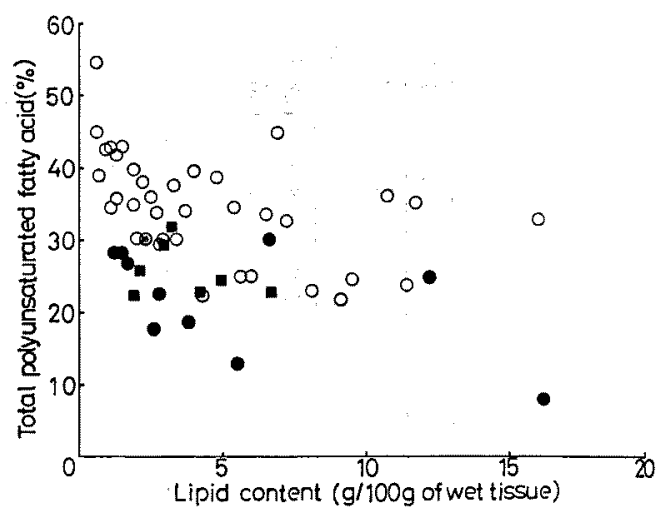

Fig. 1. Relationship between lipid content in edible portions and composition ratio of total polyunsaturated fatty acid in their lipids

- fresh water fishes except Cyprinidae (muscle); $\square$, fresh water fishes except Cyprinidae (whole body); 0 , marine fishes (muscle) [From Ohtsuru et al. $(1984)^{\text {9)}]}$

で約 5 30\% を示し，次いで $\mathrm{C}_{18: 2 \omega 6,}, \mathrm{C}_{22: 8 \omega 3,} \mathrm{C}_{30: 4 \omega 6}$

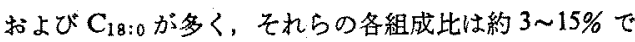
あった。

特改的なこととして，養殖つニではいずれの部位にも $\mathrm{C}_{18: 0}$ が多いこと, ウナギのフィレーには $\mathrm{C}_{18: 1 \omega \theta}$ が 30\% 以上むあり， $\mathrm{C}_{28: 608}$ が非常に少ないこと，また二 ジース，ビワマスにはどの部位でる $\mathrm{C}_{22: B \omega 3}$ が多いこと なとがあげられる。

既報の海産魚類の脂質の脂肪酸組成 ${ }^{8-8)}$ と比較すると，

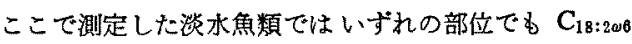

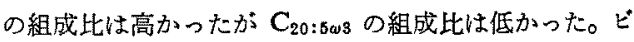
ワマス, ニシマス以外の魚種の $\mathrm{C}_{22: 8 \omega 3}$ の組成比は海産 魚類のそれよりる低かった。

ニジマス，ビワマス，才オクチバスの筋肉と小アニ, イサザの全魚体の脂質の脂肪酸組成には季節的变動が注 とんどみられなかった。

なお粗脂肪含量と高度不飽和脂肪酸 ( $\mathrm{C}_{20: 4 \omega 6}$ 以上)の 組成比との関保 (Fig，1) をみると，粗脂肪含量の高い 魚種では高度不飽和脂肪酸の占める割合が低く，粗脂肪 含量の低い魚種ではをの割合が高い傾向を示すことがか かった。また海産魚類の高度不飽和脂肪酸含量 ${ }^{6-9)}$ と比 較するとこれらの淡水魚にはをの量が一般的低いこと 毛かかった。

\section{文献}

1）小島朝子, 估藤 守, 吉中禮二, 池田静德：日 水誌, 52, 1779-1785 (1986)。

2) E. G. Bligh and W. J. Dyer: Can. J. Biochem. Physiol., 37, 911-917 (1959). 
3) 志水 莌, 多田政実, 遥藤金次：日水誌， 39 . 993-999 (1973).

4）黑川㐋雄：日水誌，49，1741-1746 (1983).

5) 在伯清子, 熊谷 洋：日水誌, 50, 1551-1554 (1984).

6) 新間弥一郎，田口格子： 日水誌，30，179-188 (1964).
7) 山田 実，林 賢治：日水誌，41，1143-1152 (1975).

8) P. G. Viswanathan Nair and K. Gopakumar: J. Food Sci., 43, 1162-1164 (1978).

9) 大鶴 勝, 藤井美由紀, 石永正隆，鬼頭 諴: 農化, 58, 35-42 (1984). 